Maria Stopa-Boryczka, Jerzy Boryczka, Urszula Kossowska-Cezak, Jolanta Wawer

University of Warsaw

Faculty of Geography and Regional Studies

Department of Climatology

e-mail: jkborycz@uw.edu.pl

\title{
HEAT AND COLD WAVES IN AN ANNUAL CYCLE AIR TEMPERATURES IN WARSAW (1951-2010)
}

\begin{abstract}
Heat and cold waves in Warsaw (the Okęcie district) have been determined determined basing on daily average air temperature values in Warsaw (the Okęcie district), measured for 60 years between 1951 and 2010. Air temperature cycles, i.e. periods, amplitudes and phases have been determined by means of a sinusoidal regression method. Especially worth noting are 15 to 18-day long cycles of air temperature in given months (e.g. 16-day long cycles during 6 months: March, April, May, August, September, and October). Heat and cold waves result from interferences of cycles whose duration ranges from several to teen days of daily temperature values, and long-term cycles of average annual temperature.
\end{abstract}

Key words: annual cycle, cold wave, heat wave, spectrum, period, amplitude, interference

\section{INTRODUCTION}

The aim of the present work is to determine regularities that occur (every several or teen days) with regard to cold and heat waves in Warsaw (the Okęcie district, 1951-2010). Annual air temperature cycle in Warsaw characterized with average monthly values does not represent the variability of weather conditions throughout the year. In order to obtain a more thorough insight into the annual cycle, a day (1:00 a.m. - 12:00 p.m.) has been assumed a unit of time (Kossowska-Cezak, Skrzypczuk; 2006).

Significant fluctuation has been noted in the annual cycle of air temperature in Warsaw, i.e. average daily temperature $(T)$ in the years 1951-2010, as well as the lowest $\left(T_{\min }\right)$ and the highest $\left(T_{\max }\right)$ values in the 60-year period. Frequent and significant changes in the cycle of 60 -year average values evidence to periodical fluctuations. If it had not been the case, i.e. if the fluctuations had been irregular, these frequent and significant changes would have been "eliminated" in such a long term (1951-2010). 


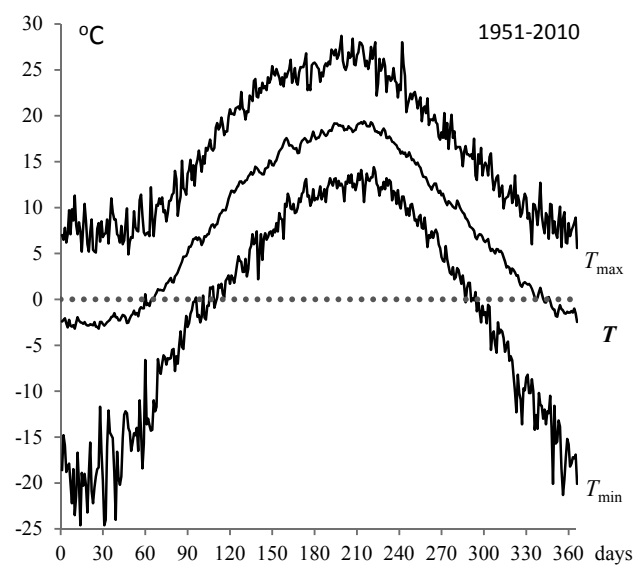

Fig. 1. Annual air temperature cycle in Warsaw (1951 - 2010)

$T$ - daily average, $T_{\min }$ - the lowest, and $T_{\max }-$ the highest in the 60 -year period
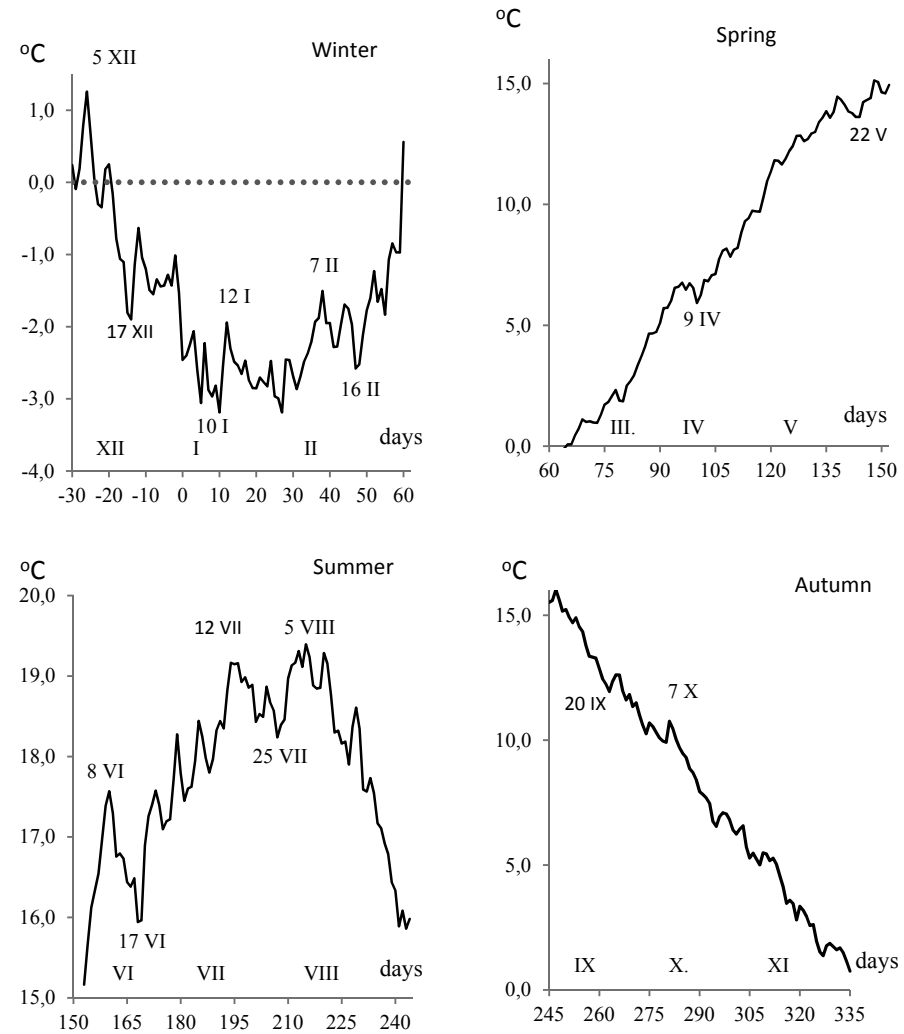

Fig. 2. Average daily 60-year temperature values in Warsaw Winter, Spring, Summer, Autumn (1951-2010) 
Timing of some drops and increases in average (during the 60-year period) daily air temperature values (i.e. temperature drops and increases) in given seasons have been presented in Figure 2. For instance, between $5^{\text {th }}$ and $8^{\text {th }}$ December, an average 60-year temperature dropped by $1.6{ }^{\circ} \mathrm{C}$ (from +1.3 to $-0.3^{\circ} \mathrm{C}$ ), and between $10^{\text {th }}$ and $12^{\text {th }}$ it increased by $1.3^{\circ} \mathrm{C}$ (from -3.2 to $\left.-1.9^{\circ} \mathrm{C}\right)$. Between $16^{\text {th }}$ and $29^{\text {th }}$ February there was a rise in air temperature by as much as $3.3^{\circ} \mathrm{C}$ (from -2.6 to $0.6^{\circ} \mathrm{C}$ ). Similarly, in summer between $1^{\text {st }}$ and $8^{\text {th }}$ June, an average 60 -year temperature value increased by $2.4{ }^{\circ} \mathrm{C}$ (from 15.2 to $17.6{ }^{\circ} \mathrm{C}$ ). Slightly less profound fluctuation in air temperature values become more noticeable in the transitional seasons, due to a strong upward tendency $1.9^{\circ} \mathrm{C} / 10^{\mathrm{d}}$ during spring time $\left(T=0.186 t-11.98, R^{2}=0.992\right)$ and downward tendency $-1.7^{\circ} \mathrm{C} / 10^{\mathrm{d}}$ during autumn $\left(T=-0.166 t+56.54, R^{2}\right.$ $=0.984)$.

\section{AIR TEMPERATURE CYCLES IN WARSAW LASTING FROM SEVERAL TO TEEN DAYS}

Limiting the unit of time to a day enables to identify periods of temperature change that last from several to teen days.

Cycles of air temperature in Warsaw in the years 1951-2010 that last from several to teen days (in an annual course) and from several to teen years (in a long-term course) have been identified by means of a sinusoidal regression method (Boryczka, 1998):

$$
y=a_{0}+b \sin \left(\frac{2 \pi}{\Theta} t+c\right)
$$

where: $\Theta$ period, $b$ - amplitude, $c$ - phase difference, $t$ - time, by changing a period of a sinusoid $\Theta$ every 0.1 day and 0.1 year. Progression of residual variance values $\varepsilon^{2}$, referring to the associated periods $\Theta$ - this is a spectrum of a variable $y$. Periods $\Theta$ - these are local minimal values of residual variance $\varepsilon^{2}$ (local maximum values of correlation coefficient $R=\left(1-\varepsilon^{2} / s^{2}\right)^{0.5}, s^{2}$ - variance of a variable $y$ ).

Interference of the identified air temperature cycles (a resultant of the cycle overlapping) has been established on the basis of the following formula:

$$
T=f(t)=a_{0}+\sum_{\mathrm{j}=1}^{\mathrm{k}} b_{\mathrm{j}} \sin \left(\frac{2 \pi}{\Theta_{\mathrm{j}}} t+c_{\mathrm{j}}\right)
$$

Parameters of the indentified cycles in annual course of air temperature: $\Theta, b, c$ in each month and season have been presented in Table 1 and 2. 
Table 1. Periods $\Theta$ (days), amplitudes $b\left({ }^{\circ} \mathrm{C}\right)$, phases $c$ of cycles of average daily air temperature values in Warsaw (1951-2010), $R$ - multiple correlation coefficient, $F_{\text {obl }}$ - the Fisher-

Snedecor distribution $\left(\mathrm{F}_{0.05}=3.35, F_{0.10}=2.52\right)-$ months

\begin{tabular}{|c|c|c|c|c|c|c|c|c|c|c|c|}
\hline M & $\Theta$ days & $b^{\circ} \mathbf{C}$ & $c$ & $R$ & $F_{\text {obl }}$ & M & $\Theta$ days & $b^{\circ} \mathbf{C}$ & $c$ & $R$ & $F_{\text {obl }}$ \\
\hline \multirow{3}{*}{ I } & 5.4 & 0.202 & -0.2661 & 0.403 & 2.71 & \multirow{3}{*}{ VII } & 6.3 & 0.136 & -2.1860 & 0.232 & 0.80 \\
\hline & 9.9 & 0.181 & -0.3840 & 0.361 & 2.09 & & 8.3 & 0.149 & -2.2650 & 0.300 & 1.38 \\
\hline & 15.5 & 0.175 & 1.8131 & 0.295 & 1.34 & & 18.3 & 0.403 & 2.9550 & 0.714 & 14.52 \\
\hline \multirow{3}{*}{ II } & 7.4 & 0.308 & 2.6971 & 0.468 & 3.64 & \multirow{3}{*}{ VIII } & 7.9 & 0.198 & 1.6408 & 0.206 & 0.62 \\
\hline & 10.5 & 0.071 & -2.8780 & 0.255 & 0.91 & & 10.3 & 0.093 & -2.8663 & 0.212 & 0.66 \\
\hline & 17.6 & 0.297 & -1.3452 & 0.470 & 3.69 & & 15.9 & 0.117 & 0.1305 & 0.453 & 3.62 \\
\hline \multirow{3}{*}{ III } & 7.8 & 0.136 & 0.8056 & 0.188 & 0.51 & \multirow{3}{*}{ IX } & 6.0 & 0.245 & -2.0286 & 0.206 & 0.62 \\
\hline & 10.4 & 0.153 & -2.8289 & 0.317 & 1.57 & & 10.2 & 0.096 & -0.0172 & 0.307 & 1.46 \\
\hline & 16.4 & 0.232 & -2.9287 & 0.478 & 4.13 & & 15.7 & 0.299 & -1.7595 & 0.389 & 2.50 \\
\hline \multirow{3}{*}{ IV } & 7.7 & 0.190 & 2.7024 & 0.252 & 0.95 & \multirow{3}{*}{ X } & .0 & 0.134 & 2.0192 & 0.181 & 0.48 \\
\hline & 10.7 & 0.233 & -1.1793 & 0.246 & 0.90 & & 10.7 & 0.167 & -2.9162 & 0.204 & 0.61 \\
\hline & 15.7 & 0.168 & 0.6207 & 0.325 & 1.65 & & 16.0 & 0.462 & -2.6124 & 0.272 & 1.12 \\
\hline \multirow{3}{*}{ V } & 6.3 & 0.126 & 1.5993 & 0.218 & 0.70 & \multirow{3}{*}{$\mathrm{XI}$} & 7.7 & 0.022 & 2.0368 & 0.205 & 0.61 \\
\hline & 10.4 & 0.290 & -2.2842 & 0.397 & 2.63 & & 10.2 & 0.416 & -2.5540 & 0.179 & 0.46 \\
\hline & 16.5 & 0.228 & 2.3874 & 0.485 & 4.30 & & 15.2 & 0.165 & -2.6389 & 0.356 & 2.03 \\
\hline \multirow{3}{*}{ VI } & 7.3 & 0.229 & 2.9757 & 0.384 & 2.42 & \multirow{3}{*}{ XII } & 4.6 & 0.241 & 0.0433 & 0.235 & 0.82 \\
\hline & 10.6 & 0.314 & 2.9427 & 0.485 & 4.30 & & 7.7 & 0.404 & -2.1011 & 0.339 & 1.82 \\
\hline & 16.8 & 0.540 & -1.3462 & 0.648 & 10.15 & & 16.8 & 0.350 & -1.4969 & 0.367 & 2.17 \\
\hline
\end{tabular}

Table 2. Periods $\Theta$ (days), amplitudes $b\left({ }^{\circ} \mathrm{C}\right)$, phases $c$ of cycles of average daily air temperature values in Warsaw (1951-2010), $R$ - multiple correlation coefficient, $F_{\text {obl }}$ - the Fisher-

Snedecor distribution $\left(\mathrm{F}_{0.05}=3.09, F_{0.10}=2.36\right)$ - seasons and year

\begin{tabular}{|c|c|c|c|c|c|c|c|c|c|c|c|}
\hline M & $\begin{array}{c}\Theta \\
\text { days }\end{array}$ & $b^{\circ} \mathbf{C}$ & $c$ & $\boldsymbol{R}$ & $\mathbf{F}_{\text {obl }}$ & M & $\begin{array}{c}\Theta \\
\text { days }\end{array}$ & $b^{\circ} \mathbf{C}$ & $c$ & $\boldsymbol{R}$ & $\mathbf{F}_{\text {obl }}$ \\
\hline \multirow{5}{*}{ Winter } & 7.9 & 0.287 & -2.1124 & 0.208 & 1.97 & \multirow{5}{*}{ Spring } & 13.2 & 0.064 & 0.3616 & 0.64 & 13.2 \\
\hline & 16.6 & 0.143 & -1.7657 & 0.165 & 1.22 & & 18.6 & 0.062 & -1.6743 & 1.02 & 18.6 \\
\hline & 20.9 & 0.453 & 2.9338 & 0.378 & 7.25 & & 23.3 & 0.306 & 2.1394 & 1.23 & 23.3 \\
\hline & 28.3 & 0.224 & 1.1875 & 0.246 & 2.80 & & 31.0 & 0.487 & 0.9624 & 2.08 & 31.0 \\
\hline & 40.7 & 0.313 & -0.8861 & 0.288 & 3.95 & & 47.1 & 0.402 & -2.8337 & 7.78 & 47.1 \\
\hline \multirow{5}{*}{ Summer } & 12.4 & 0.253 & 1.9860 & 0.207 & 1.95 & \multirow{5}{*}{ Autumn } & 9.1 & 0.112 & -0.0325 & 0.37 & 9.1 \\
\hline & 14.4 & 0.202 & 0.4927 & 0.179 & 1.44 & & 18.2 & 0.111 & -2.2731 & 1.32 & 18.2 \\
\hline & 17.5 & 0.425 & 0.1510 & 0.292 & 4.04 & & 22.9 & 0.098 & -1.6228 & 1.50 & 22.9 \\
\hline & 27.5 & 0.344 & 0.6678 & 0.222 & 2.26 & & 30.8 & 0.291 & 0.9806 & 4.40 & 30.8 \\
\hline & 38.8 & 0.528 & -2.5854 & 0.379 & 7.29 & & 47.7 & 0.082 & 1.1252 & 8.22 & 47.7 \\
\hline \multirow{5}{*}{ Year } & 34.9 & 0.725 & -3.1213 & 0.064 & 0.18 & & & & & & \\
\hline & 66.6 & 1.158 & 3.1176 & 0.105 & 0.48 & & & & & & \\
\hline & 81.6 & 1.686 & 3.1360 & 0.151 & 1.01 & & & & & & \\
\hline & 105.0 & 1.880 & 2.9052 & 0.167 & 1.25 & & & & & & \\
\hline & 147.9 & 3.450 & 3.0666 & 0.310 & 4.64 & & & & & & \\
\hline
\end{tabular}


For instance, spectrum of changes in average daily air temperature values in Warsaw (1951-2010) in May and December (Fig. 3). Periods of 10th and 16th days in May, and 8th and 17th days in December are the major minimal values of residual variance $\mathrm{e}^{2}$.
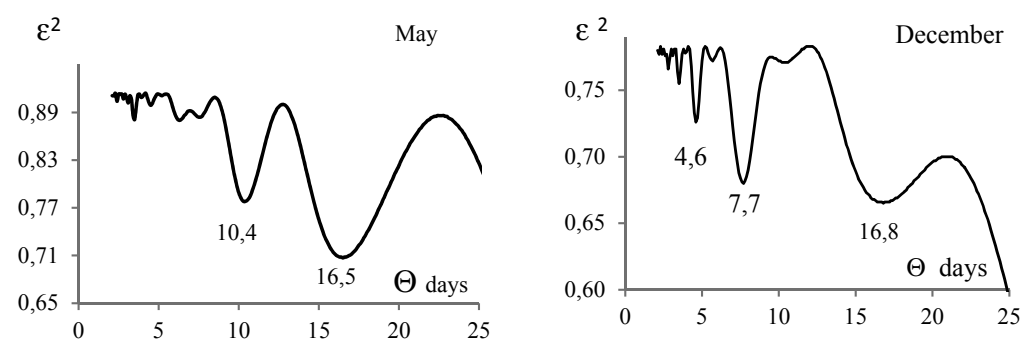

Fig. 3. Spectrum of changes in average daily air temperature values in Warsaw (1951-2010) - May, December.

It is worth taking a closer look at 15.2- to 18.3-day cycles of air temperature in given months (Table 3): about 16 days in the following months: March, April, May, August, September and October, about 15 days in January and November, about 17 days in June and December, about 18 days in February and July.

Air temperature fluctuations are the most visible $\left(1^{\circ} \mathrm{C}\right)$ in June in a 16.8 day cycle and also in July (in a 18.3-day cycle), October (a 16.0-day cycle) and December (a 16.8-day cycle) the fluctuations are rather significant, i.e. $0.8,0.9,0.7^{\circ} \mathrm{C}$

Table 3. Range of air temperature fluctuation in 15.2 - to 18.3 -day cycles and the timing of maximum $\left(\mathrm{t}_{\max }\right)$ and minimum $\left(\mathrm{t}_{\min }\right)$ values

\begin{tabular}{|l|r|c|r|r|r|r|r|r|r|r|r|r|}
\hline & \multicolumn{1}{|c|}{ I } & II & \multicolumn{1}{c|}{ III } & \multicolumn{1}{c|}{ IV } & \multicolumn{1}{c|}{ V } & VI & VII & VIII & IX & X & XI & XII \\
\hline$\Theta$ days & 15,5 & 17,6 & 16,4 & 15,7 & 16,5 & 16,8 & 18,3 & 15,9 & 15,7 & 16,0 & 15,2 & 16,8 \\
\hline $2 b\left({ }^{\circ} \mathrm{C}\right)$ & 0,35 & 0,59 & 0,46 & 0,34 & 0,46 & 1,08 & 0,81 & 0,23 & 0,60 & 0,92 & 0,33 & 0,70 \\
\hline$t_{\min }$ & 7,1 & 17,0 & 3,5 & 10,2 & 6,1 & 16,2 & 5,1 & 11,6 & 0,5 & 2,7 & 2,6 & 16,6 \\
\hline$t_{\max }$ & 14,9 & 8,2 & 11,7 & 2,4 & 14,4 & 7,8 & 14,3 & 3,6 & 8,4 & 10,7 & 10,2 & 8,2 \\
\hline
\end{tabular}

It is likely that these half-month periods are linked to Moon and Sun tides on the Earth. During full moon and half moon, Moon and Sun tides sum up. The average intervals between appearance of the same celestial longitude of the Sun and the Moon amount to some $29^{\mathrm{d}} .53$ (lunation).

An annual course of average 60 -year daily values of air temperature in Warsaw (1951-2010) is well illustrated (correlation coefficient $R=0.997, n=$ 366) by a sinusoidal equation with a period $\Theta=365.25$ days:

$$
T=7.676+0.002245 t+10.76845 \sin (2 \pi t / 365.25-1.8456)
$$

with an amplitude $2 b=21.53{ }^{\circ} \mathrm{C}$ 


\section{LONG-TERM CYCLES OF COLD AND HEAT WAVES IN WARSAW (1951-2010)}

An average annual air temperature in Warsaw is subject to a long-term periodicity. Thus, several- to teen-year cycles influence the amplitudes of several- to teen-day cycles. Spectra of average monthly air temperature values in Warsaw in the years 1951-2010 in May and December have been presented as an example (Fig. 4)
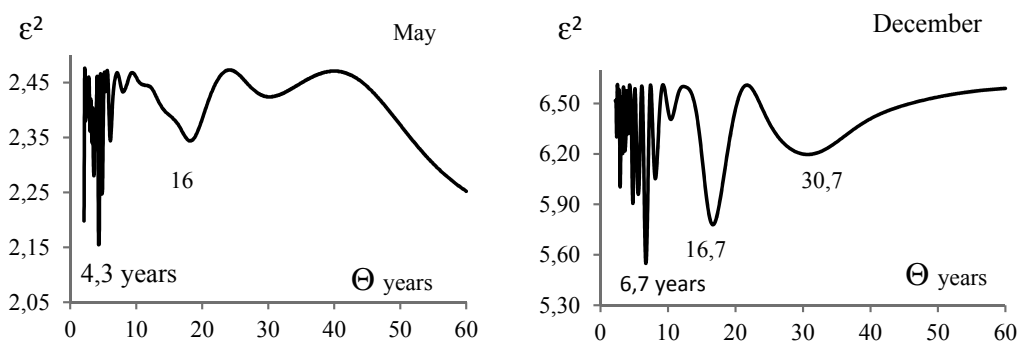

Fig. 4. Spectra of average monthly air temperature values in Warsaw (1951-2010) - May, December

The parameters of air temperature cycles in Warsaw (1951-2010) have been listed in Table 4

Table 4. Periods $\Theta$ (years), amplitudes $b\left({ }^{\circ} \mathrm{C}\right)$, phases $c$ of cycles of average monthly and yearly air temperature values in Warsaw (1951-2010), $R$ - multiple correlation coefficient, $F_{\text {obl }}-$ the Fisher-Snedecor distribution $\left(F_{0.05}=3.16, F_{0.10}=2.39\right)$ - seasons and year

\begin{tabular}{|l|c|c|c|c|c|}
\hline \multirow{4}{*}{ May } & $\boldsymbol{\Theta}$ years & $\boldsymbol{b}^{\circ} \mathbf{C}$ & $\boldsymbol{c}$ & $\boldsymbol{R}$ & $\boldsymbol{F}_{\text {0bl }}$ \\
\hline & 4.3 & 0.800 & -1.4951 & 0.359 & 4.21 \\
\cline { 2 - 6 } & 6.1 & 0.533 & 1.1244 & 0.229 & 1.57 \\
\cline { 2 - 6 } & 8.0 & 0.280 & 0.7592 & 0.128 & 0.47 \\
\cline { 2 - 6 } & 18.2 & 0.440 & 1.1087 & 0.229 & 1.57 \\
\cline { 2 - 6 } & 30.2 & 0.107 & 1.3869 & 0.141 & 0.58 \\
\hline \multirow{4}{*}{ December } & 2.9 & 1.078 & -2.2656 & 0.300 & 2.83 \\
\cline { 2 - 6 } & 6.7 & 1.348 & -0.8855 & 0.401 & 5.45 \\
\cline { 2 - 6 } & 8.1 & 0.843 & -2.4279 & 0.291 & 2.63 \\
\cline { 2 - 6 } & 16.7 & 1.101 & 0.9660 & 0.355 & 4.11 \\
\hline \multirow{4}{*}{ Year } & 30.7 & 0.742 & -2.0437 & 0.250 & 1.91 \\
\cline { 2 - 6 } & 5.9 & 0.324 & 0.7761 & 0.280 & 2.43 \\
\cline { 2 - 6 } & 8.1 & 0.578 & 2.7540 & 0.483 & 8.66 \\
\cline { 2 - 6 } & 9.9 & 0.236 & 0.6532 & 0.175 & 0.90 \\
\hline & 15.6 & 0.266 & -1.5115 & 0.239 & 1.73 \\
\hline
\end{tabular}




\section{COLD AND HEAT WAVES IN MAY, AND WEATHER-RELATED SAYINGS}

The most oft-cited cold wave in May is the one between the 12 th and 14th of May - so called "Ice Saints" (Polish: Zimni ogrodnicy), i.e. the feast days of St. Pancras, St. Servatus and St. Boniface of Tarsus, or the 15th of May - a so-called "Cold Sophia's" (Polish: Zimna Zośka), the feast day of St. Sophia. According to the available sources, such a colder weather was known already in the $15^{\text {th }}$ century. It is likely to be brought from the southeastern part of Poland. The most severe cold wave in this period is to be noticed in the south of Poland, while the least - in the north-eastern part of the country (Stopa-Boryczka et. al, 2006). Relatively minor temperature decreases are caused by marine polar air masses, whereas the major ones by arctic air masses (on average $8^{\circ} \mathrm{C}$ ). During a warm season, advection of cold marine polar air masses from Western Europe to southern Poland contribute to occurrence of severe cold waves. In the north-eastern part of Poland, however, a region characterized with the lowest values of air temperature (excl. the mountains), marine polar and arctic air masses do not result in such significant decreases in air temperature as in the south of the country.

60-year average daily air temperature values in May are characterized with 6.3-, 10.6- and 16.5-day periods. The strongest is a 16.5-year cycle with the amplitude $2 b=0.45^{\circ} \mathrm{C}$ (correlation coefficient $R=0.473, F_{\text {obl }}=4.0$ ) significant at the level of 0.05 . The interference of these May cycles is determined in the function with the multiple correlation coefficient $R=$ 0.972:

$$
\begin{aligned}
& T=12.089+0.09216 t+0.126 \sin (2 \pi t / 6.3+1.5993)+0.290 \sin (2 \pi t / 10.4-2.2842)+ \\
& 0.228 \sin (2 \pi t / 16.5+2.3874)
\end{aligned}
$$

In long-term cycles: encompassing 4.3, 6.1, 8.0, 18.2, 30.2-year periods, the air temperature changed respectively by $1.6,1.06,0.88,0.20^{\circ} \mathrm{C}$. The greatest amplitude $\left(1.6{ }^{\circ} \mathrm{C}\right)$ has been noted for a 4.3 -year cycle $(R=0.359$, $F_{\text {obl }}=4.21$, significant at the level of 0.05).

Responsible for occurrence of the May cold waves are the following cycles: 16.5-day and 4.3-year periods of the major fluctuation range $0.46{ }^{\circ} \mathrm{C}$ and 1.6 ${ }^{\circ} \mathrm{C}$ (fig. 4 and 5). Colder weather in May (minimal values of air temperature) results first of all from the interference of 16.5-day and 4.3-year cycles (fig. 5 and 6$)$. 


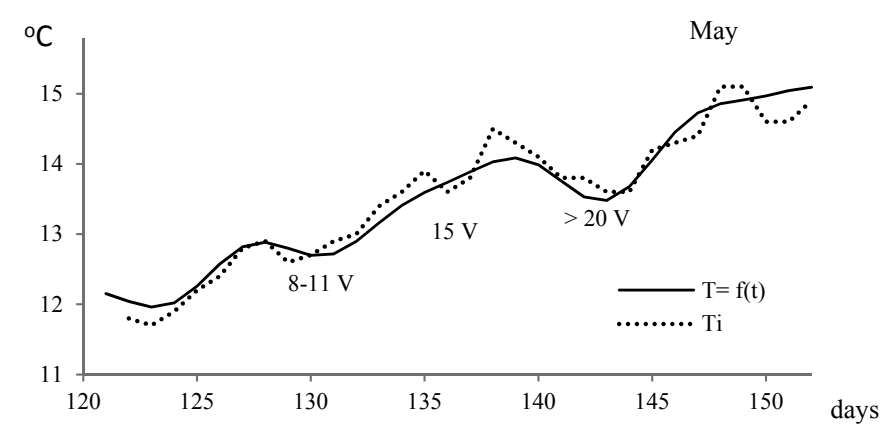

Fig. 5. Cycle of average daily air temperature values in Warsaw (1951-2010), $T_{\mathrm{i}}$ - measured values, $T=f(t)-$ calculated values (interference of $6.3,10.6,16.5$-day cycles) - May

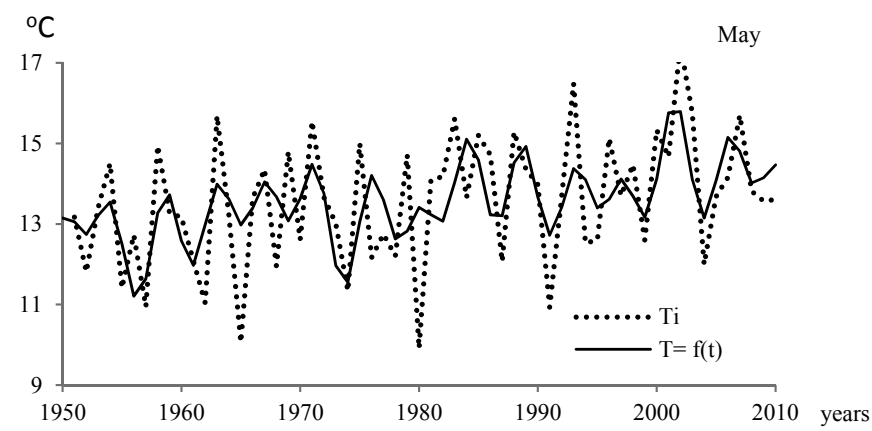

Fig. 6. Cycle of average monthly air temperature values in Warsaw (1951-2010), $T_{\mathrm{i}}$ - measured values, $T=f(t)$ - calculated values (interference of 4.3, 6.1, 8.0, 18.2, 30.2-year cycles, correlation coefficient $R=0.589$ ) - May

\section{COLD AND HEAT WAVES IN DECEMBER, AND WEATHER-RELATED SAYINGS}

Many authors have so far researched heat and cold waves in December, or i.e. verifiability of the following Polish saying "Saint Barbara on ice, Christmas on water" (Polish: Święta Barbara po wodzie, Boże Narodzenie po lodzie) (see: Gumiński 1948, Chrzanowski 1973). Between 1951 and 2000 this saying proved right in 20 cases (40\%), whereas the verifiability of the opposite saying "Saint Barbara on ice, Christmas on water" (Polish: Święta Barbara po lodzie, Boże Narodzenie po wodzie) was two times lower (Tońska 2006).

One cannot expect to prove compliance of air temperature fluctuations, basing solely on the two following dates: the $4^{\text {th }}$ and $25^{\text {th }}$ of December. In the years 1951-2000,the most air temperature values noted in the days around the $4^{\text {th }}$ December were above $0^{\circ} \mathrm{C}$ (Figs. 7 and 8 ). 
60-year average daily air temperature values in December (1951-2010) are characterized with the following periods: $6.6,7.7$ and 16.8 days with the fluctuation scope of $0.48,0.81$ and $0.70{ }^{\circ} \mathrm{C}$.

Interference of these cycles is determined in the following function (multiple correlation coefficient $R=0.954)$ :

\section{$T=0.575-0.0831 \mathrm{t}+0.241 \sin (2 \pi t / 4.6+0.0433)+0.404 \sin (2 \pi t / 7.7-2.1011)+$ $0.350 \sin (2 \pi t / 16.8-1.4969)$}

Whereas in the long-term cycles of average annual air temperature, that is $2.9,6.7,8.1,16.7,30.7$-year periods, fluctuation scope $2 b$ is respectively $2.1,2.7,1.6,2.2,1.5^{\circ} \mathrm{C}$. The strongest cycles in December are 6.7 and 16.7year periods with significant correlation coefficients of $0.401\left(F_{\mathrm{obl}}=5.45\right)$ and $0.365\left(F_{\mathrm{obl}}=4.11\right)$.

Heat and cold waves in December $\left(5^{\text {th }}\right.$ and $25^{\text {th }}$ December) are conditioned by the following cycles of daily air temperature values:7.7 and 16.8-day periods, as well as cycles of average annual air temperature, that is 6.7 and 16.7-year periods with amplitudes of 0.60 and $0.44^{\circ} \mathrm{C}$, and 2.7 and $2.2{ }^{\circ} \mathrm{C}$, respectively. Changes in 6-year average daily air temperature values in December (from the 1 st to the 31 st of the month) have been illustrated in diagrams in figure 7.

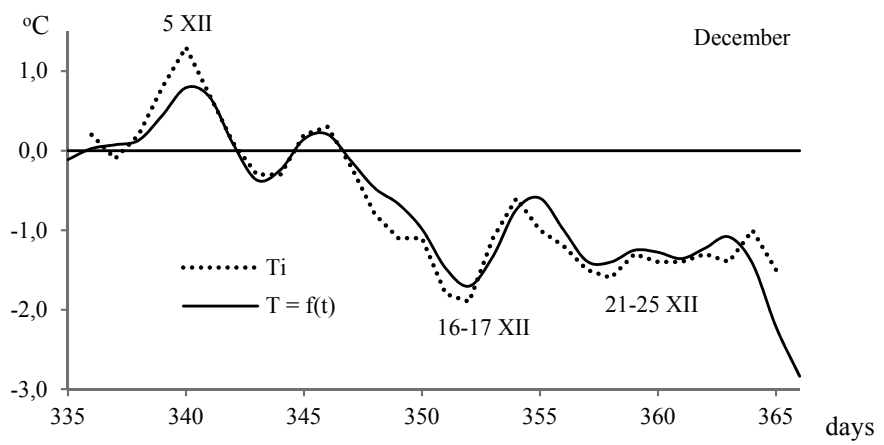

Fig. 7. Cycle of average daily air temperature values in Warsaw (1951-2010), $T_{\mathrm{i}}-$ measured values, $T=f(t)-$ calculated values (interference of 4.6,7.7, 16.8-day cycles) - December

The maximum value of a resultant $T=f(t)$ of an interference between strong 8 and 17-day air temperature cycles is noticeable on the 4 th December (Saint Barbara's feast day), while the minimum value is recorded after the 16 th and around the 25th December (Christmas). In the years with the average monthly air temperature much below zero $\left(T<0{ }^{\circ} \mathrm{C}\right)$, the 4 th December brings colder weather.

Warm and cold spells on the 4 th December (temperature $T_{4}$ ) have been compared with warm and cold spells on the 25th December $\left(-T_{25}\right)$ and the sign $T_{25}$ has been changed to the opposite one (fig. 8). The positive air tem- 
perature values $\left(T_{4}>0 \mathrm{i}-T_{25}>0\right)$ prove that the heat waves on the $4^{\text {th }}$ of December correspond the cold waves on the $25^{\text {th }}$ of December. Correspondence of negative values occurrence dates $\left(T_{4}<0\right.$ and $\left.-T_{25}<0\right)$, i.e. below the $T=0$ line, evidences to the fact that the opposite saying is right, namely "Saint Barbara's $4^{\text {th }}$ December on ice, Christmas $-25^{\text {th }}$ December - on water" (Polish: Święta Barbara po lodzie, Boże Narodzenie po wodzie).

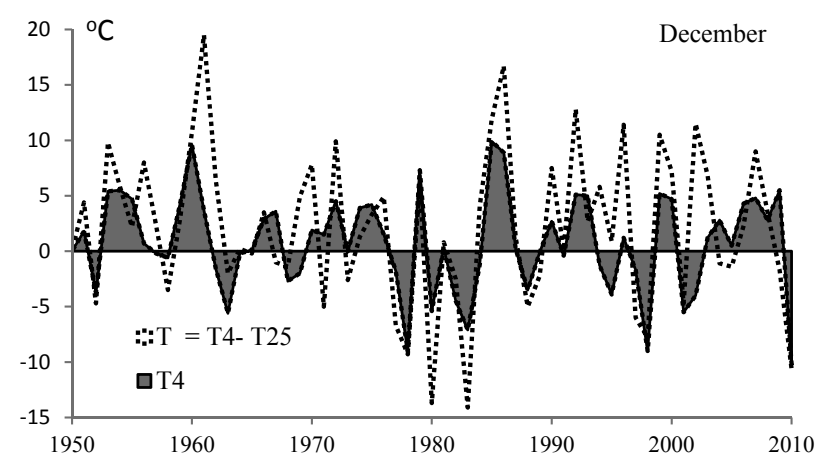

Fig. 8. Cycle of air temperature in Warsaw on the 4th of December (St. Barbara's feast day, $\left.T_{4}\right)$ and on the 25th of December (Christmas, $\left.-T_{25}\right)(1951-2010)$

In the years 1951-2010 there were 36 years with temperature values $T_{4}$ $\geq 0{ }^{\circ} \mathrm{C}$ (4th of December), of which there were 22 years with the temperature values $T_{25}<0^{\circ} \mathrm{C}$ (25th of December) (Table 4 ). The ratio of cases compliant with the saying (verifiability) Saint Barbara (4 ${ }^{\text {th }}$ December) on water, Christmas (25 ${ }^{\text {th }}$ December) on ice" (Polish: Święta Barbara po wodzie, Boże Narodzenie po lodzie, to the total number of years (60) amounts to $36.7 \%$, and to the favourable years (36) - 61.1\%. During 24 years with the temperature values $T_{4}<0{ }^{\circ} \mathrm{C}$ (4th December) there are 10 days with the temperature values $T_{25}>0$ (25th December). The total verifiability of the saying (St. Barbara on water and on ice) is $53.3 \%$.

Long-term changes in air temperature values in the years 1951-2010 in December and in winter prove worthwhile (Figs. 9 and 10).

The outcomes of the conducted research show that the cold and heat waves result from overlapping of significant, several to teen-day cycles of daily air temperature and long-term (several to teen-year) cycles of average annual air temperature. It is worth taking a closer look at 15.2- to 18.3-day cycles of air temperature in given months: about 16 days in the following months: March, April, May, August, September and October, about 15 days in January and November, about 17 days in June and December, about 18 days in February and July. Heat and cold waves in December on the $4^{\text {th }}$ (St. Barbara's feast day) and $25^{\text {th }}$ (Christmas) of December are conditioned by the following cycles of daily air temperature values: 7.7 and 16.8 days (with amplitudes $(2 b)$ of 0.8 and $0.7^{\circ} \mathrm{C}$ ), and the 6.7 and 16.7 -year cycles of average 
Table 4. Air temperature values on the $4^{\text {th }}$ and $25^{\text {th }}$ of December in Warsaw (1951-2010) that comply with the conditions of the saying "Saint Barbara on water", Christmas on ice".

\begin{tabular}{|c|c|c||c|c|c|c|c|c|}
\hline \multicolumn{7}{|c|}{ "Saint Barbara on water" } & \multicolumn{3}{c|}{ "Saint Barbara on ice" } \\
\hline & $\boldsymbol{T}_{\mathbf{4}}>\mathbf{0}$ & $\boldsymbol{T}_{\mathbf{2 5}}<\mathbf{0}$ & & $\boldsymbol{T}_{\mathbf{4}}>\mathbf{0}$ & $\boldsymbol{T}_{\mathbf{2 5}}<\mathbf{0}$ & & $\boldsymbol{T}_{\mathbf{4}}>\mathbf{0}$ & $\boldsymbol{T}_{\mathbf{2 5}}<\mathbf{0}$ \\
\hline 1985 & 9.9 & -2.0 & 1966 & 2.9 & -0.6 & 2010 & -10.2 & 0.4 \\
\hline 1960 & 9.6 & -1.1 & 2008 & 2.8 & -0.7 & 1978 & -9.0 & 0.3 \\
\hline 1986 & 8.9 & -7.8 & 1990 & 2.7 & -4.8 & 1983 & -7.1 & 7.0 \\
\hline 1954 & 5.5 & -0.3 & 1970 & 1.9 & -5.9 & 1980 & -5.4 & 8.3 \\
\hline 1953 & 5.4 & -4.4 & 1951 & 1.8 & -2.6 & 1952 & -3.7 & 1.0 \\
\hline 1999 & 5.2 & -5.3 & 1976 & 1.5 & -3.4 & 1988 & -3.5 & 1.5 \\
\hline 1992 & 5.1 & -7.7 & 1996 & 1.2 & -10.2 & 1977 & -1.8 & 4.9 \\
\hline 2007 & 4.8 & -4.2 & 2003 & 1.2 & -5.6 & 1997 & -1.7 & 4.3 \\
\hline 2000 & 4.7 & -2.5 & 1956 & 0.7 & -7.3 & 1958 & -0.6 & 2.9 \\
\hline 1972 & 4.5 & -5.4 & 1981 & 0.3 & -0.5 & 1989 & -0.1 & 2.1 \\
\hline 1961 & 3.7 & -15.8 & 1987 & 0.2 & -1.0 & & & \\
\hline
\end{tabular}

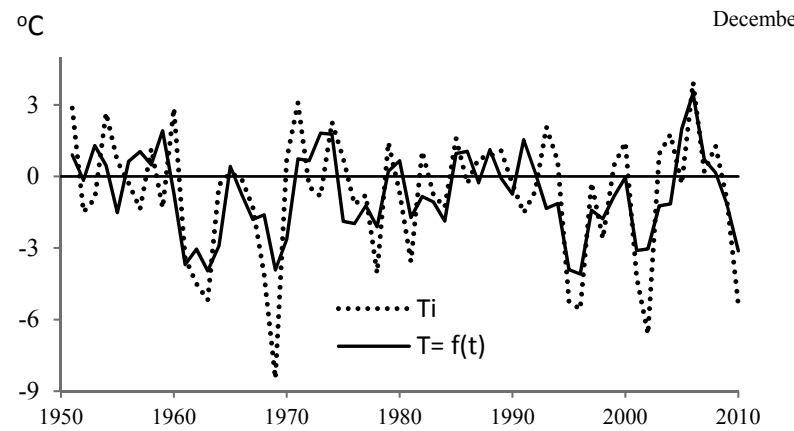

Fig. 9. Cycle of average monthly air temperature values in Warsaw (1951-2010), $T_{\mathrm{i}}$ - measured values, $T=f(t)-$ calculated values (interference of $2.9,6.7,8.1$. 16.7, 30.7-year cycles, correlation coefficient $R=0,589)$ - December

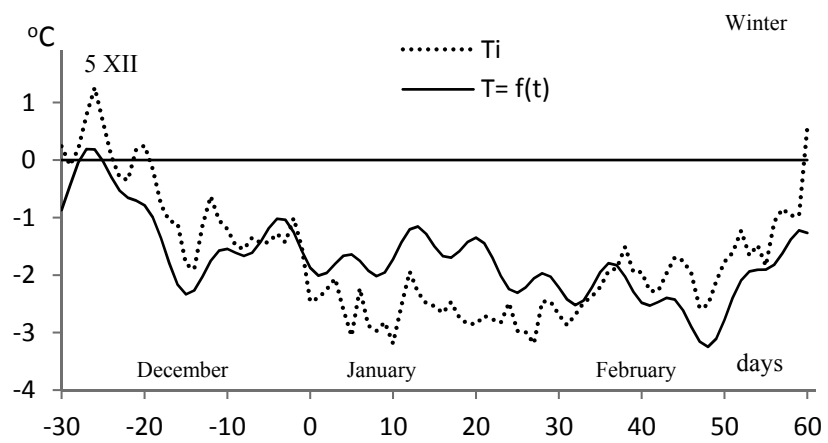

Fig. 10. Cycle of average daily air temperature values in Warsaw (1951-2010), $T_{\mathrm{i}}$ - measured values, $T=f(t)$ - calculated values (interference of $7.9,16.6,20.9,28.3,40.7$-days cycles, correlation coefficient $R=0.660$ ) - Winter 
annual air temperature (with amplitudes of 2.7 and $2.2^{\circ} \mathrm{C}$ ). The maximum value of the resultant $T=f(t)$ of an interference of strong 60-year average daily air temperature cycles lasting 7.7 and 16.8 days occurs on the 5th December, while the minimum value occurs after the 16th December and around the 25th December.

It would be also interesting to analyze the annual and long-term periodicity in types of atmospheric circulation and other elements of climate.

\section{BIBLIOGRAPHY}

Boryczka J., 2010, Metoda J. Boryczki „sinusoid regresji” badań okresowości zmiennych przyrodniczych [Jerzy Boryczka's 'regression sinusoid' metod for studying periodicity natural variables] [in:] Atlas wspótzależności parametrów meteorologicznych i geograficznych $w$ Polsce, $v$. XXV, Zmiany klimatu Warszawy i innych miast Europy $w$ XVII-XXI wieku, Wyd. UW, Warszawa

Chrzanowski J., 1973, Barbara po lodzie [When 4th December is cold]. „Problemy”, 12

Gumiński R., 1948, Ludowe prognostyki pogody [Traditional weather forecasting]. Gazeta obserwatora PIHM, 1, 9

Kossowska-Cezak U., Skrzypczuk J., Termiczne pory roku $w$ Warszawie w latach 1951-2005 [Thermal seasons in Warsaw in 1951-2005]. [in:] Prognozy pogody $w$ przystowiach $i$ ich sprawdzalność $w$ Polsce. Materiały Zakładu Klimatologii WG i SR UW z X Pikniku Naukowego Radia BIS (3 VI 2006). Wyd. WGSR UW, Warszawa

Stopa-Boryczka M., Boryczka J, Tońska M., 2006, Fale chtodu $i$ ciepła $w$ przebiegu rocznym temperatury powietrza $w$ Polsce [Cold and heat waves in annual air temperature fluctuations in Polnad]. [in:] Prognozy pogody $w$ przystowiach $i$ ich sprawdzalność $w$ Polsce. Materiały Zakładu Klimatologii WG i SR UW z X Pikniku Naukowego Radia BIS (3 VI 2006). Wyd. WG i SR UW, Warszawa

Tońska M., 2006, Wartość prognostyczna niektórych przysłów dotyczqcych pogody [Prognostic value of some weather proverbs.] Master's thesis at Zakład Klimatologii WG and SR UW (supervisor: Jolanta Wawer) 